\title{
APPLICATION OF INDUSTRIAL DESIGN IN GREEN AREAS
}

\author{
Katerina Despot, Vaska Sandeva \\ Goce Delcev University of Stip, Macedonia \\ Krste Misirkov b.b. P.O. Box 201 Stip 2000, Macedonia, \\ e-mail: katerina.despot@ugd.edu.mk, vaska.sandeva@ugd.edu.mk
}

\begin{abstract}
The existence of green areas is essential for quality of life in every living space. Application of industrial design in parks and gardens has an important role and nowadays is very common. The impact of industrial design in urban green spaces in residential areas provides dedicated aesthetic note that enriches the whole functional and aesthetic forms which are always placed at precise positions that accentuate the landscape, while the cohesion and harmony are combined and contrasts nature in industrial design.

The design is created as an artwork in a predetermined order. The artwork gets the role of usability and functional aesthetics. The design evolves with the development of industry and mass consumption.

Industrial fragments in green areas make artwork that is unique and are one of a kind.
\end{abstract}

Keywords: design, park, city, composition, landscape.

\section{INTRODUCTION}

"Dynamic composition" is frequently used expression when speaking of modern parks. The expression is often associated with the ability to move, to change mood and mutual relationship of all elements in the full expression of the park. The composition represents forms within a given expanse.

Setting up forms and elements depends of the desired effect. In the narrow sense, composition can be defined as an image, or better yet image-composition of free or geometric figures that are found in any dependency on each other. The compositions depend on a number of objective factors, among which the aesthetic requirements take an important part.

As a scientific discipline, the theory of composition has its own categories, those are tectonic structure and volume - spaciousness structure.

\section{THE COMPOSITION IN THE ART OF PARK IMPLIES COMBINING ELEMENTS AND PRINCIPLES IN BUILDING A PARK.}

\subsection{Convergent line}

If one pays attention to the convergent lines such as roads, railroads, sidewalks or shadows, it is noticeable that these lines will direct one's gaze to distant parts, making the view more dynamic.

\subsection{Rhythmic elements}

The rhythmically repeated elements, such as trees, benches, people - or any group that repeats, forms a resting feeling for visitors, but small variations in the composition brings out liveliness and makes it more interesting.

IRITIE Vol. 4, No. 1, 2016 ISSN 1314-8788 (print), ISSN 1314-8796 (online), doi: 10.15547/artte.2016.01.009 


\section{IRTIIE $<>$}

Ipplied Reseirlches in Teechnics, Technologies ind Bduration

Journal of the Faculty of Technics and Technologies, Trakia University https://sites.google.com/a/trakia-uni.bg/artte/

\subsection{Elements that overlap}

Overlapping of elements in the scenery, partially covering objects creates a sense of mystery. It is creating more depth by creation of space in the view.

\subsection{Shaping of elements}

Elements that give shape to the space such as trees, urban equipment, doorways form a framework that will focus the viewer's attention to the point of interest. This technique provides excellent results with any zoom setting. Proper composition can matter great deal in building a park. The park should not just represents a picture, but a work of art that will offer pleasant feeling and lot of content. Composition is a matter of relations in a park. Every composition has its own specific factors such as:

- Concept or idea;

- Material which achieves the idea;

- Form for composition;

- Elements for composition.

Effective expression of the artist's (photographer's) idea is the main objective of any composition, and it can be expressed only in a composition that is in place and related to make a firm and clear synthesis. Synthesis means unity, and unity is what makes the creation (pictured) giving a strong impression even upon first contact with the viewer.

Given that the first and strongest impression comes from the visual elements that give the momentary and direct effect on viewer's feelings, the artist (photographer) should seek his expression to flow more through them than through thematic content. After all, the viewer does the intellectual reading of the thematic content gradually and much later.

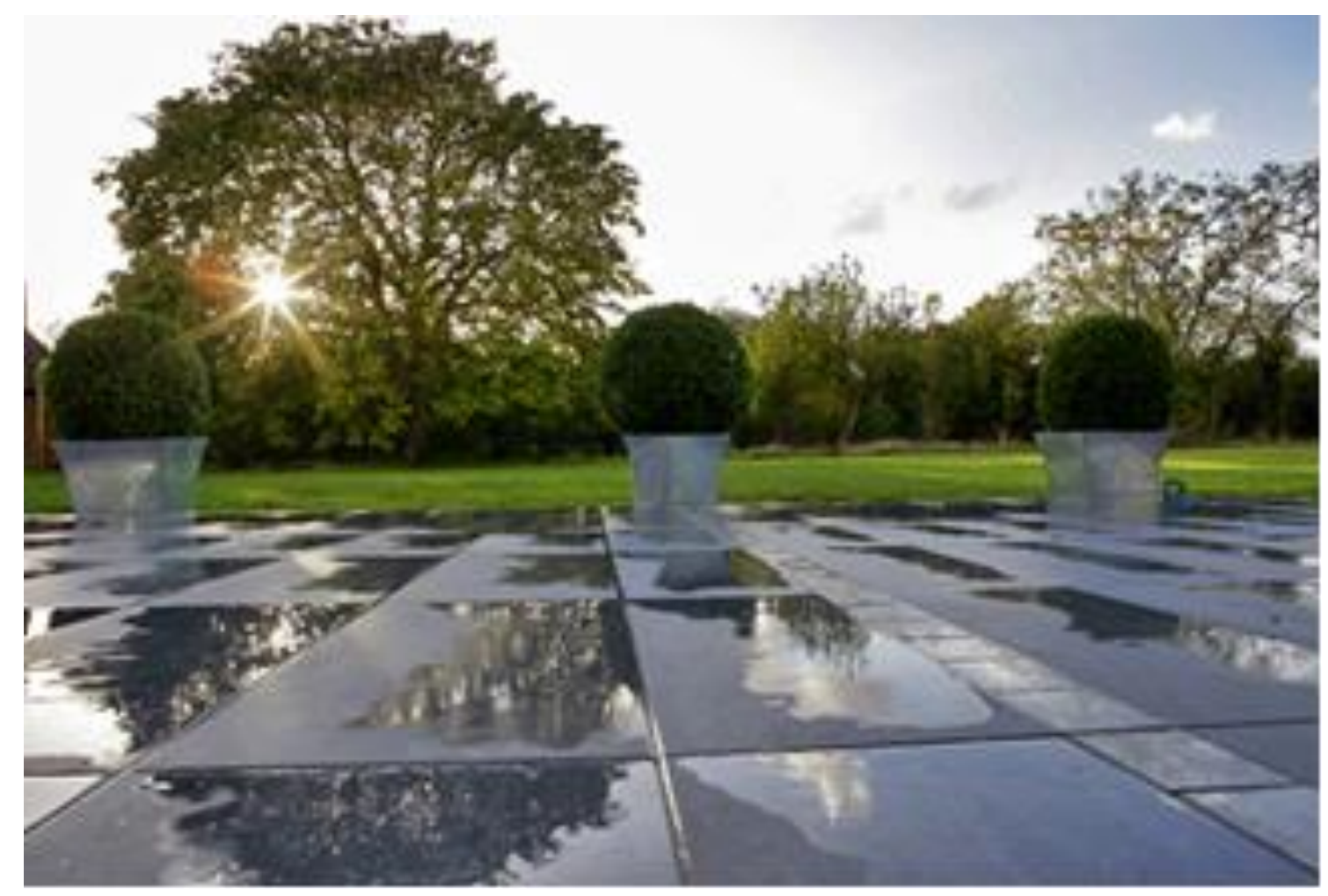

Figure 1. Effects in the park

IRITIE Vol. 4, No. 1, 2016 ISSN 1314-8788 (print), ISSN 1314-8796 (online), doi: 10.15547/artte.2016.01.009 


\section{ARTTE $Y$}

Ipplied Researrches in Technics, Technologies and Bduration

Journal of the Faculty of Technics and Technologies, Trakia University https://sites.google.com/a/trakia-uni.bg/artte/

Park art - Park art is a way through which a person maintains the surrounding natural environment. With the deviation of pagan beliefs before religious beliefs the park art evolved and began to express ideas and other functions. In the advanced stages of society development gardens turn into an object of visual pleasure and a way for the superiority of man over everything else to be shown. The approach of people towards nature gives vigor to think they govern it. This opinion was dominated at the time of the Italian Renaissance.

Art can be divided into three categories:

1. Spatial - arts that exist only in space - art, architecture and applied arts.

2. Temporal - which only exists in time - music, literature.

3. Spatial-temporal - exists in space and in time - dance, theater, and cinema.

Therefore park art is spatial-temporal because the spatial created work, park or garden exists in space and time at the same time.

Park art belongs to the category of spatial - temporal fine art and complex art.

Park art is a creative activity that aims to create a purposeful organic material environment for communication between man and nature which are charged with content of modern and cool new trends of the fast and dynamic life.

\section{Features of the park art}

- Emotions - the ability to express specific feelings;

- Cognition - with its help people enrich their knowledge;

- Nationality - it forms the love and empathy towards national tradition;

- Realism - art is aligned with some purpose and characteristics (efficiency).

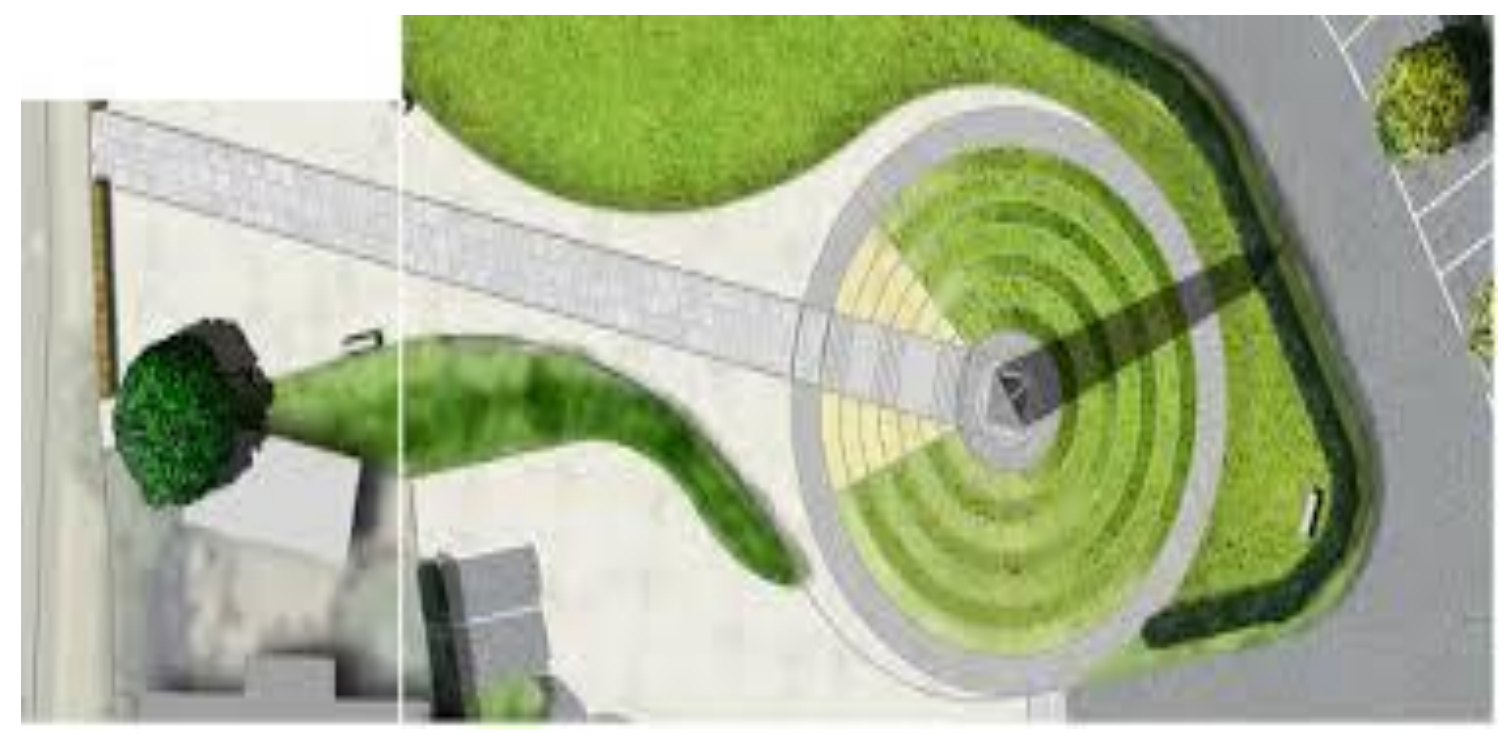

Figure 2. Composition

Industrial design is a creative activity to determine external quality of industrially manufactured items. The term industrial design can be treated as a term that denotes the area or discipline that means a finished product. Industrial design is an area that is directly derived from modern technology, where mass production and distribution of spent goods creates demand that can be satisfied with the quality products to the needs of man.

Therefore interdisciplinary and multidisciplinary treatment of the design is correct and true approach, using multiple scientific disciplines in the development of products or methodology of industrial design.

IRTIIE Vol. 4, No. 1, 2016 ISSN 1314-8788 (print), ISSN 1314-8796 (online), doi: 10.15547/artte.2016.01.009 


\section{ARTTIE Y}

Ipplied Researches in Technics, Technologies ind Bduration

Journal of the Faculty of Technics and Technologies, Trakia University https://sites.google.com/a/trakia-uni.bg/artte/

The design is a creative activity whose aim is to establish multilateral quality of facilities, processes, services and their systems in the whole life cycle. That is why design is the key, a central factor in innovative humanization of technologies and the crucial factor of cultural and economic change.

Industrial design is an industrial property that relates to a specific look or form of body, painting, drawing, contour, composition, color, texture or their combination thereof it meets the requirements of novelty and individual character to those previously known to public. Industrial design gives products a certain visual aesthetic, ergonomic, practical purpose or quality that distinguishes them from other products on the market.

Industrial design services are often provided in the context of cooperation and working relationship with other members of the development group. Typical groups include management, marketing, engineering and manufacturing specialists. The unique contribution of the industrial designer is emphasizing those aspects of a product or system that relate the most to human characteristics, needs and interests. This contribution requires an understanding of visual, tactile, safety and convenience criteria, with concern for the user. Education and experience in anticipating psychological, physiological and sociological factors that affect the user, are considered as essential industrial design resources.

They work to prove that design recommendations use materials and efficient technologies, in accordance with all legal and regulatory requirements.

Industrial design has a dual application. It serves to satisfy the need of a good and useful. By its nature and by its shape, with which it presents to the public, it is located halfway between the invention and the "pure" art.

The legal protection of industrial design consists in protecting the distinctive elements that are responsible for the success on the market. The legal protection of industrial design among other things intensifies the investment in resources that nurture it, pushing design as an element of production. Protection of industrial design is determined in different ways depending on the country. Industrial design is an applied art that enhances aesthetic and use values of the products.
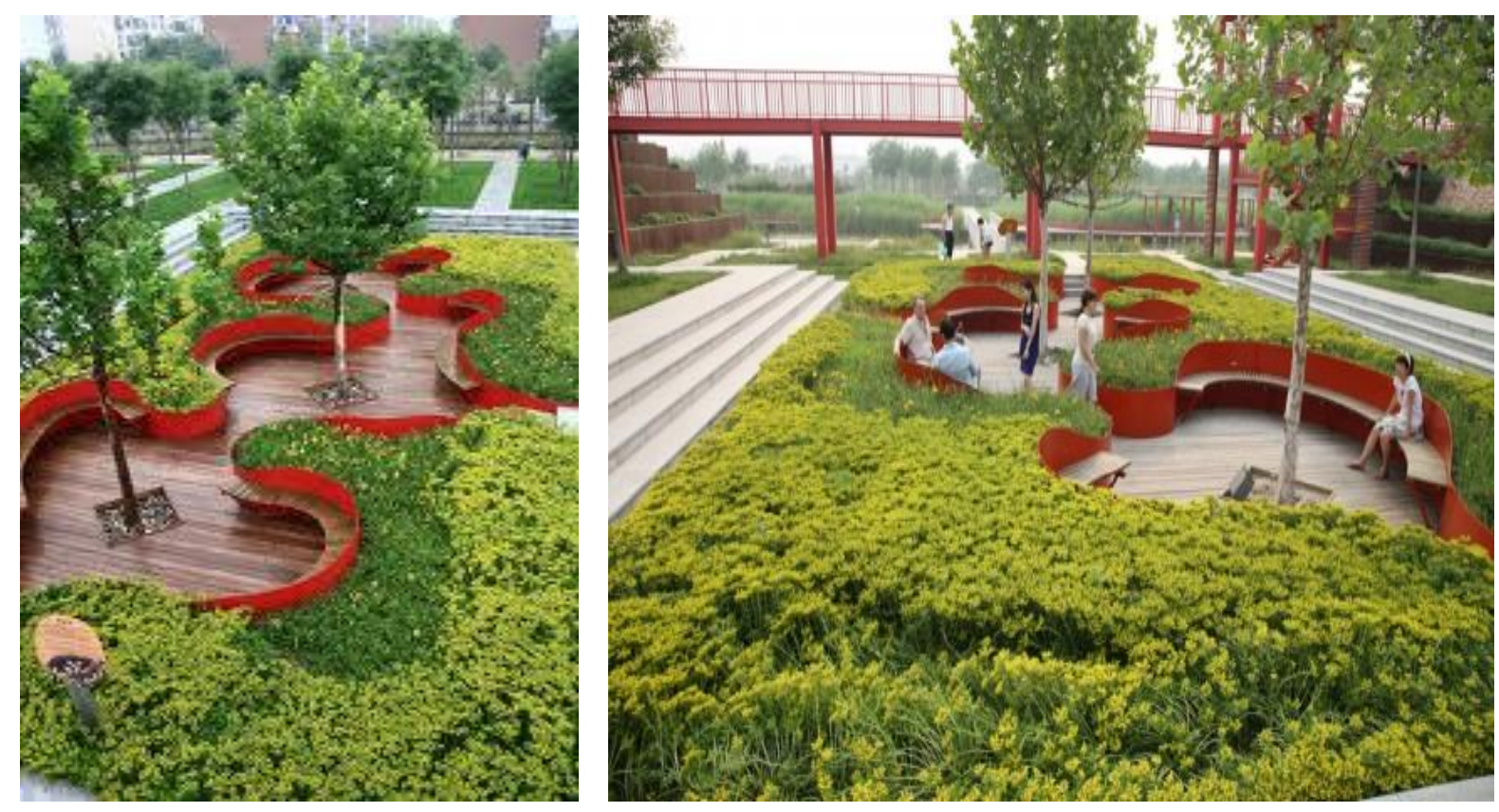

Figure 3. Complete clarity and functionality

IRITIE Vol. 4, No. 1, 2016 ISSN 1314-8788 (print), ISSN 1314-8796 (online), doi: 10.15547/artte.2016.01.009 


\section{IRTIIE}

Ipplied Reseitreches in Technicss, Technologies ind Bducation

Journal of the Faculty of Technics and Technologies, Trakia University https://sites.google.com/a/trakia-uni.bg/artte/

The link between the park and the industrial design - the reason for setting up industrial objects is primarily adding functional segments in a park which is complemented with decorative content and shows us modern trends.

Specific features of park art and industrial design are as follows: scale, dynamics of development, availability and understandable character.

Scale - artistic principle, which defines the relationship of the dimensions of individual components and elements between them and toward the whole. The scale is also widely used in industrial and manufactured items because they are related to ergonomics.

There are two types of scales in a park:

- Relative - when surface or volumes cause optical performance for different scales in the same size of the entire area.

- Human - distinguishing the volumes and surface areas in such ratios that are associated with generally accepted medium dimensions of the human figure and the reach of his perception.

- Dynamic of development - the basic material that is alive suffers continuous changes.

- Available and understandable character.

The application of the scale in a park and related industrial scale give the complete composition of the future park.

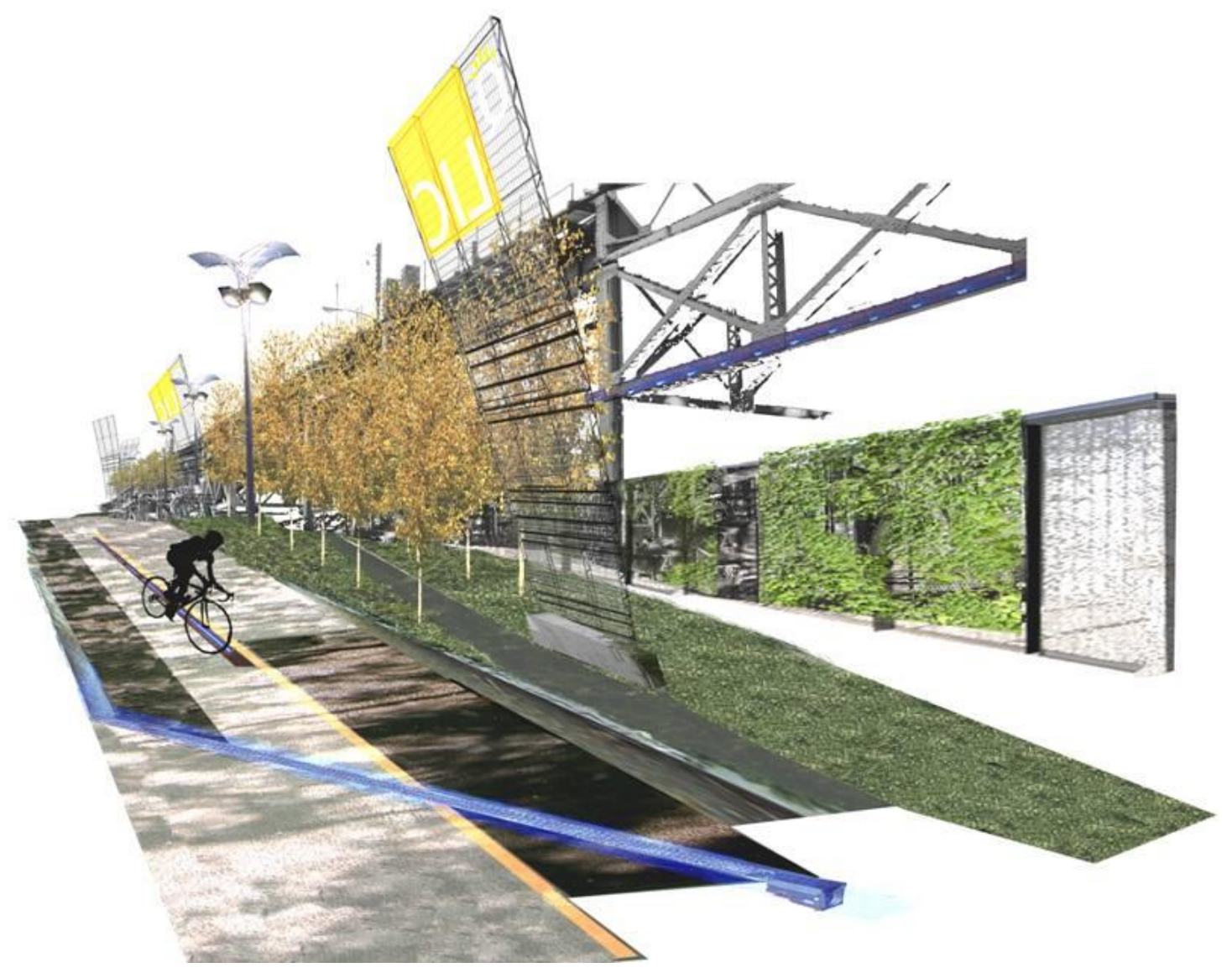

Figure 4. Industrial design in the park 


\section{ARTTIE $Y$}

Ipplied Researches in Technics, Technologies ind Bduration

Journal of the Faculty of Technics and Technologies, Trakia University https://sites.google.com/a/trakia-uni.bg/artte/

\section{CONCLUSION}

The composition is very important element in the landscape design and industrial design. It makes exterior spaces much more pleasant while overpassing. Thus we can conclude that various compositions are compatible with one another and in combination fit perfectly into the design of the landscape, but also have to do with the ideal blend of all elements that make up the whole.

Short definition of industrial design would say: the design represents determining and shaping of the quality and the attitude of manufactured items, cleaning, communications, systems, processes and environment satisfying conditions of production, distribution and use of interdisciplinary methodology.

When accurately determined and placed in the composition of the park they have a dual role they have strictly defined functions and their second purpose is sculptural decoration which gives parks a modern and contemporary look, their setting gives industrialized look which is the right concept for large cities. The idea is for the visitors to rest and yet, not to forget the everyday.

\section{LITERATURE}

[1] Kovachev A. (2005). The green system of Sofia. Urban aspects (historical development, present state, problems and trends, strategy and forecasts). Sofia-Moscow, PenSoft.

[2] Kuleliev J. (1992). Landscaping settlements. Sofia, PenSoft.

[3] Fruht. M. (1981). Industrial Design. Beograd.

[4] Fruht. M. (1991). Design Theory. Beograd.

[5] Lisiyska Z. (1994). The design base: Theory, Hystory, Methodology. Blagoevgrad.

[6] Trandafilov A., Rizova I., Kancheva K., Gradinarov N., Gurdzhieva S. (1989). Ergonomics of Design. Sofia, Central Institute of Industrial Aesthetics.

[7] Penov G. Ergonomics. Sofia.

[8] Ivanova N. (1984). History of Design. Sofia. 